\title{
Pengaruh Corporate Governance, Capital Intensity dan Profitabilitas Terhadap Tax Avoidance pada Sektor Pertambangan
}

\author{
Jumriaty Jusman ${ }^{1}$, Firda Nosita ${ }^{2 *}$ \\ ${ }^{1,2}$ STIE Pancasetia Banjarmasin \\ J1. A. Yani KM. 5,5 Banjarmasin \\ ${ }^{*}$ Correspondence email: firda.nosita@gmail.com
}

\begin{abstract}
Abstrak. Penelitian ini bertujuan untuk mengetahui pengaruh corporate governance, capital intensity, dan profitabilitas terhadap tax avoidance. Mekanisme corporate governance yang digunakan adalah kualitas audit dan komite audit, sedangkan profitabilas diproksikan dengan ROA. Tax avoidance diproksikan dengan Cash Effective Tax Rate. Dengan menggunakan metode purposive sampling, sampel yang digunakan adalah sebanyak 21 perusahaan dari sektor pertambangan yang terdaftar di BEI selama periode 2016-2018. Hasil penelitian menunjukkan bahwa secara simultan kualitas audit, komite audit, capital intensity dan ROA berpengaruh signifikan terhadap tax avoidance. Sedangkan secara parsial kualitas audit, komite audit, dan capital intensity tidak berpengaruh signifikan terhadap tax avoidance. Sedangkan ROA berpengaruh negatif signifikan terhadap penghindaran pajak.
\end{abstract}

Kata kunci: Penghindaran Pajak; Kualitas Audit; Komite Audit; Capital Intensity; ROA

Abstract. The study aims to examine the influence of Corporate Governance, Capital Intensity and Profitability on Tax Avoidance. The proxy of Corporate governance was audit quality and audit committee, while the profitability factor used is Return on Asset (ROA) and Tax Avoidance by Cash Effective Tax Rate. The sample was chosen by purposive sampling and resulted 21 companies from mining sector listed oin Indonesian Stock Exchange from 2016 to 2018. The data analyzed by using multiple linier regression. The result showed that audit quality, audit committee, and capital intensity have insignificant influence on tax avoidance. While ROA has negative significant on tax avoidance

Keywords: Tax Avoidance; Corporate Governance; Capital Intensity; Profitability; Cash Effective Tax Rate.

\section{PENDAHULUAN}

Pajak merupakan sumber utama dan sumber pendapatan Negara terbesar. Data dari Kemenkeu pada tahun 2019 sekitar 1.786,4 T dana APBN berasal dari penerimaan perpajakan. Melalui pajak, pemerintah dapat menjalankan program-programnya dalam tujuan meningkatkan pertumbuhan ekonomi melalui pembangunan infrastruktur, aset-aset publik, dan fasilitas umum lainnya. Hal tersebut menjadi suatu bukti bahwa penerimaan pajak sangat diandalkan dalam pendapatan Negara. Mengingat peran pajak sangat besar bagi Negara, maka pemerintah berupaya untuk meningkatkan penerimaan dari sektor pajak. Pemerintah Indonesia sendiri dari tahun ke tahun semakin gencar melakukan optimalisasi pajak dengan salah satu cara untuk mewujudkan kemandirian bangsa dalam pembiayaan pembangunan adalah dengan menggali sumber dana dari pajak. Namun usaha optimalisasi penerimaan pajak oleh pemerintah ini juga memiliki beberapa kendala. Salah satu kendala optimalisasi penerimaan pajak oleh pemerintah adalah penghindaran pajak atau segala sesuatu yang dilakukan perusahaan untuk meminimalkan biaya pajak perusahaan.

Penghindaran pajak atau biasa disebut dengan tax avoidance secara umum dapat dikatakan suatu skema penghindaran pajak untuk tujuan meminimalkan beban pajak dengan memanfaatkan celah (loophole) ketentuan perpajakan suatu negara. Sedangkan menurut Justice
Reddy dalam kasus McDowell \& Co Versus CTO di Amerika Serikat, tax avoidance sebagai seni menghindari pajak tanpa melanggar hukum. Penghindaran pajak sering dikaitkan dengan perencanaan pajak (tax planning), di mana keduanya samasama menggunakan cara yang legal untuk mengurangi atau bahkan menghilangkan kewajiban pajak. Akan tetapi, perencanaan pajak tidak diperdebatkan mengenai keabsahannya, sedangkan penghindaran pajak merupakan sesuatu yang secara umum dianggap sebagai tindakan yang tidak dapat diterima. Walaupun secara literal tidak ada hukum yang dilanggar, semua pihak sepakat bahwa penghindaran pajak merupakan sesuatu yang secara praktik tidak dapat diterima. Hal ini dikarenakan penghindaran pajak secara langsung berdampak pada tergerusnya basis pajak, yang mengakibatkan berkurangnya penerimaan pajak yang dibutuhkan oleh negara.

Upaya penghindaran pajak dari perusahaan global juga terjadi di berbagai negara di dunia. Bahkan khusus di Uni Eropa sendiri penghindaran pajak diperkirakan merugikan keuangan anggota Uni Eropa 1 triliun euro atau Rp 12.000 triliun di tahun 2012. Begitu besarnya penghindaran pajak yang dilakukan perusahaan global tersebut menjadi salah satu fokus Direktorat Jenderal (Ditjen) Pajak tahun ini. Hal itu disebut intensifikasi pajak dari perusahaan Penanaman Modal Asing (PMA). Jaringan perusahaan PMA di berbagai negara memang 
Jumriaty Jusman dan Firda Nosita, Pengaruh Corporate Governance, Capital Intensity dan Profitabilitas Terhadap Tax Avoidance pada Sektor Pertambangan

memungkinkan upaya penghindaran pajak. Pengalaman inggris menggambarkan penghindaran pajak dilakukan secara terstruktur. Akhir tahun 2012, badan pajak Inggris HMRC (HM Revenue and Customs) menisik pelaporan pajak 4 perusahaan global. Pertama, kasus franchisor kedai kopi asal Amerika Serikat (AS). Parlemen Inggris menyoroti laporan keuangan franchisor yang menyatakan rugi sebesar 112 juta pounds selama tahun 2008-2010 dan tidak membayar pajak PPh (pajak penghasilan) badan pada 2011. Dalam laporan ke investor, franchisor menyatakan omzet selama 2008-2010, senilai 1,2 milyar pounds (Rp 18 triliun). Kasus kedua yaitu laporan pajak perusahaan internet search engine kakap berbasis di AS. Perusahaan ini meraih revenue di Inggris 398 juta pounds pada tahun 2011, tapi hanya membayar pajak 6 juta pounds. Keuntungan perusahaan cabang Inggris kemudian ditransfer ke cabang di Irlandia, Belanda dan berakhir di Bermuda. Negara Bermuda adalah tax havens country yang tidak memungut $\mathrm{PPh}$ badan. Kasus ketiga, pajak bonus karyawan investment banking dari AS. Agar pembayaran bonus ini tidak terdeteksi, karyawan investment banking cabang Inggris diminta mengajukan permohonan pinjaman lunak ke investment banking cabang AS. Dengan dalih pinjaman lunak, karyawan investment banking cabang Inggris tidak harus membayar pajak penghasilan. Atas kecurangan ini, investment banking cabang Inggris harus membayar denda 500 juta pounds (Rp 7,5 triliun). Kasus keempat, skandal bunga pinjaman Perusahaan Air Minum (PAM) swasta Inggris. PAM ini meminjam dari induknya di Hongkong yang mengeluarkan eurobond melalui tax havens countries di Channel Islands dan Cayman Island. Anak usaha di Inggris meminjam dari induknya lebih dari 1 milyar pounds (Rp 15 triliun) dengan suku bunga 11 persen atau sekitar Rp 1,65 triliun per tahun (Gusnita, 2013). Sedangkan di Indonesia, laporan yang belum lama dikeluarkan oleh Global Witness cukup menghebohkan. Laporan itu menyebutkan bahwa perusahaan tambang besar di Indonesia, PT Adaro Energy Tbk melakukan akal-akalan pajak. Adaro disebut melakukan transfer pricing melalui anak usahanya di Singapura, Coaltrade Services International. Upaya itu disebutkan telah dilakukan sejak 2009 hingga 2017. Adaro diduga telah mengatur sedemikian rupa sehingga mereka bisa membayar pajak US\$ 125 juta atau setara Rp 1,75 triliun (kurs Rp 14 ribu) lebih rendah daripada yang seharusnya dibayarkan di Indonesia (Sugianto,2019).

Indonesia merupakan pemain kunci dalam percaturan industri pertambangan batu bara dunia. Selama puluhan tahun, industri batu bara selalu dianakemaskan oleh Negara lantaran kontribusinya lebih besar dalam perekonomian nasional. Bahkan, kala krisis ekonomi global 2008 melanda, berkat sumbangsih industri batubara kondisi ekonomi Indonesia masih tetap tumbuh. Posisi tersebut membuat pelaku industri pertambangan batu bara relatif tidak mendapatkan pengawasan yang memadai, sehingga acap kali terjadi kasus kerusakan lingkungan dan praktik-praktik immoral berupa penghindaran pajak (tax avoidance). Batubara merupakan sumber energy paling primadona. Saat ini hamper $40 \%$ sumber pembangkit listrik dunia bersumber dari batu bara. Walaupun tren pemanfaatan energy terbarukan makin tinggi dan bauran energy yang bersumber dari air, angina, cahaya matahari dan panas bumi dengan energy "kotor" yang bersumber dari batu bara dan minyak bumi, namun batu bara masih akan menjadi pilihan utama dalam memproduksi energy. Menurut BP Energy Outlook 2018, batu bara masih akan berkontribusi setidaknya $30 \%$ sebagai sumber energy pembangkit listrik dunia. Selain digunakan sebagai sumber energy pembangkit listrik, batu bara juga merupakan bahan untuk berbagai komoditas industri lain. Batubara digunakan untuk bahan campuran kertas, pupuk, plastik, baja dan keramik. Selain itu batu bara dimanfaatkan sebagai sumber panas untuk produksi semen dan gas alam.

Tax avoidance memiliki makna upaya yang dilakukan untuk menghindari pajak (penghindaran pajak). Penghindaran pajak (tax avoidance) didefinisikan sebagai salah satu tindakan yang dilakukan wajib pajak untuk mengurangi beban pajaknya secara legal. Secara lebih jelas, tax avoidance dapat didefinisikan sebagai suatu upaya mendeteksi celah dalam ketentuan perundang-undangan perpajakan hingga ditemukan titik kelemahan dari perundangan tersebut yang memungkinkan untuk dilakukannya penghindaran pajak yang dapat menghemat besaran pajak yang dibayarkan. Dari definisi tersebut, tax avoidance adalah upaya yang dilakukan oleh wajib pajak baik perorangan maupun badan hukum atau usaha untuk meminimalisir pembayaran pajak. Fenomena penghindaran pajak di Indonesia dapat dilihat dari rasio pajak (Tax Ratio). Kinerja pemungutan pajak negara dapat dilihat dari rasio pajak yang dapat dikumpulkan oleh negara.

Akan tetapi, terdapat dampak buruk yang menyertai aktivitas penghindaran pajak. Dalu et al. (2012) menyebutkan bahwa sebuah negara yang menghadapi peningkatan jumlah penggelapan pajak dan penghindaran pajak cenderung menunjukkan investasi campuran yang berproduktif rendah, yang mana hal ini berarti pertumbuhan ekonomi rendah dan perusahaan publik akan terkena dampak negatif. Penghindaran pajak yang merupakan strategi pajak agresif yang dilakukan untuk meminimalkan beban pajak akan dapat menyebabkan meningkatnya risiko untuk perusahaan seperti denda dan reputasi perusahaan yang buruk di mata publik (Rizal, 2016). Penghindaran pajak juga dapat dilakukan oleh perusahaan dengan praktik-praktik ilegal, atau seringkali disebut dengan tax evasion. 
Apabila dilihat dari besarnya peluang perusahaan untuk melakukan penghindaran pajak, maka diperlukan tata kelola perusahaan yang baik dengan konsep good corporate governance (GCG). Supaya sistem atau mekanisme perusahaan menjadi lebih baik untuk menciptakan nilai tambah (value added) untuk semua Stocholders, karena corporate governance merupakan sistem atau mekanisme yang mengatur dan mengendalikan perusahaan. Perusahaan merupakan salah satu wajib pajak sedangkan corporate governance menjelaskan hubungan antar berbagai partisipan dalam perusahaan yang menentukan arah kinerja perusahaan, sehingga dengan adanya corporate governance memiliki andil dalam pengambilan keputusan, termasuk dalam keputusan hal memenuhi kewajiban pajaknya (Cahyono, 2016).

Corporate governance dapat digunakan untuk mencegah agen melakukan usaha yang agresif dalam pengelolaan beban pajak perusahaan. Desai dan Dhammapala (2009) telah membuktikan bahwa kebijakan dalam pengelolaan beban pajak pada perusahaan dipengaruhi oleh penerapan corporate governance. Corporate governance yang tinggi akan menyebabkan wajib pajak tidak agresif dalam pengelolaan pajak untuk meningkatkan kinerja perusahaan dan memaksimalkan pengembalian kepada pemegang saham, sehingga terciptanya lingkungan kerja manajemen yang bersih, transparan dan profesional. Semakin baik corporate governance perusahaan telah dijalankan sesuai peraturan dan melaksanakan pengawasannya secara efektif terhadap benturan kepentingan serta kecurangan yang dilakukan oleh perusahaan untuk melakukan tax avoidance.

Aktivitas audit yang dilakukan oleh KAP terhadap perusahaan pada hakikatnya merupakan salah satu bentuk pengawasan yang dilakukan untuk menilai kinerja dari manajemen. Dalam konteks keagenan, aktivitas pengauditan juga akan mengatasi masalah kesenjangan informasi (information asymetry) yang terjadi antara pihak manajemen dan pemegang saham. Teori agensi menyatakan adanya asimetri informasi antara manajer (agen) dan pemegang saham (prinsipal) karena manajer lebih mengetahui informasi internal dan prospek perusahaan di masa yang akan datang dibandingkan pemegang saham dan stakeholder lainnya. Dengan demikian aktivitas pengauditan merupakan pencerminan penerapan prinsip transparansi yang merupakan salah satu prinsip penerapan GCG. Kualitas audit yang baik akan membantu menyelesaikan masalah keagenan manajemen dan pemegang saham, termasuk dalam masalah keputusan tax avoidance. Hal ini sejalan oleh hasil penelitian yang dilakukan oleh Feranika et al., (2017) dan Fadhilah (2014) bahwa kualitas audit berpengaruh signifikan dengan arah yang negatif terhadap tax avoidance. Laporan keuangan yang diaudit oleh KAP The Big Four lebih berkualitas sehingga menampilkan nilai perusahaan yang sebenarnya, sehingga memiliki tingkat kecurangan pajak yang lebih rendah dibandingkan dengan perusahaan yang diaudit oleh Non The Big Four (Annisa dan Kurniasih, 2012).

Berdasarkan Keputusan Ketua Bapepam dan LK Nomor KEP-643/BL/2012, Komite Audit adalah komite yang dibentuk oleh dan bertanggung jawab kepada Dewan Komisaris dalam membantu melaksanakan tugas dan fungsi Dewan Komisaris. Dengan demikian, keberadaan komite audit membantu Dewan Komisaris dalam melakukan tugas pengawasan kepada direksi. Apabila komite audit efektif melaksanakan tugasnya dengan baik, maka kualitas pengawasan Dewan Komisaris akan lebih baik sehingga dapat membantu penyelesaikan permasalahan keagenan dalam perusahaan. Hal ini berarti bahwa keberadaan komite audit mencerminkan penerapan GCG dalam perusahaan. Aktivitas tax avoidance yang dilakukan direksi diharapkan dapat berkurang dengan adanya komite audit. Komite audit bertugas melakukan kontrol dalam proses penyusunan laporan keuangan perusahaan untuk menghindari kecurangan pihak manajemen. Berjalannya fungsi komite audit secara efektif memungkinkan pengendalian pada perusahaan dan laporan keuangan yang lebih baik serta mendukung good corporate governance (Andriyani, 2008). Keberadaan komite audit yang fungsinya untuk meningkatkan integritas dan kredibilitas pelaporan keuangan agar dapat berjalan dengan baik sehingga segala perilaku atau tindakan yang menyimpang berhubungan terkait dengan laporan keuangan bisa dihindari oleh perusahaan.

Capital Intensity adalah aktivitas investasi yang dilakukan perusahaan yang dikaitkan dengan investasi dalam bentuk asset tetap. Rasio intensitas modal dapat menunjukkan tingkat efisiensi perusahaan dalam menggunakan aktivanya untuk menghasilkan penjualan. Capital Intensity sering dikaitkan dengan seberapa besar aktiva tetap dan persediaan yang dimiliki perusahaan. Rodriguez dan Arias (dalam Pilanoria, 2016) menyebutkan bahwa aktiva tetap yang dimilki perusahaan memungkinkan perusahaan untuk memotong pajak melalui akibat depresiasi dari aktiva tetap setiap tahunnya. Hal ini mengasumsikan bahwa perusahaan dengan tingkat aktiva tetap yang tinggi memiliki beban pajak yang lebih rendah dibandingkan perusahaan yang mempunyai aktiva tetap yang rendah. Hal tersebut juga dapat dimanfaatkan celah oleh perusahaan sebagai penghindaran pajak yaitu dengan memberikan depresiasi yang besar dari aktiva tetap sehingga beban pajak berkurang. Hal ini di dukung oleh hasil penelitian yang dilakukan oleh Darsono (2015) serta penelitian oleh Dharma dan Noviari (2017) bahwa Capital Intensity berpengaruh positif dan signifikan terhadap tax avoidance.

Profitabilitas merupakan kemampuan perusahaan dalam menghasilkan keuntungan dari aktivitas bisnis. 
Peningkatan laba mengakibatkan jumlah pajak yang harus dibayar juga semakin tinggi atau dapat dikatakan ada kemungkinan upaya untuk melakukan tindakan tax avoidance. Perusahaan dengan tingkat profitabilitas yang tinggi cenderung memilki konflik kepentingan antara pemilik perusahaan (principal) dan manajer (agent) yang rendah. Karena perusahaan dianggap sudah berjalan dengan baik sesuai yang diharapkan pemilik perusahaan. Perusahaan yang memiliki kemampuan menghasilkan laba yang tinggi, harus mempersiapkan pajak atas laba yang diperoleh. Tingginya profitabilitas mengisyaratkan tingginya laba yang akan diterima perusahaan, hal ini berarti pajak yang dibayar perusahaan pun akan meningkat. Dengan didukung pendapatan yang tinggi, maka perusahaan mungkin akan menghindari untuk "memanipulasi" pajak dan cenderung taat pajak.

\section{METODE}

Populasi penelitian ini adalah semua perusahaan sektor pertambangan yang terdaftar di BEI periode 20162018. Sampel penelitian ditentukan dengan metode nonprobability sampling dengan teknik purposive sampling dengan kriteria sebagai berikut: 1) perusahaan sektor pertambangan yang tercatat pada BEI selama periode penelitian yaitu Januari 2016 sampai dengan Desember 2018; 2) Perusahaan yang menyajikan laporan keuangannya menggunakan tahun buku yang berakhir 31 Desember; 3) Perusahaan yang diteliti mencatatkan laba selama periode penelitian; 4) Perusahaan tidak yang memiliki CETR lebih dari satu; dan 5) memiliki data yang dibutuhkan sesuai indikator yang ditentukan. Populasi penelitian ini sebanyak 49 perusahaan pertambangan yang menerbitkan laporan keuangan auditan berturut-turut setiap periode. Hasil seleksi sampel dengan menggunakan purposive sampling terpilih 21 perusahaan pertambangan sebagai sampel penelitian dengan total pengamatan sebanyak 63 tahun perusahaan (2016-2018). Dari 63 pengamatan terdapat data outliers yang nilainya terlalu ekstrim sehingga dikeluarkan dari sampel maka total pengamatan menjadi 55 pengamatan.

Data dalam penelitian ini didapatkan dari laporan tahunan atau Annual Report yang diperoleh dari situs web Bursa Efek Indonesia (www.idx.co.id).

Tabel 1. Definisi Operasional Variabel

\begin{tabular}{|c|c|}
\hline Variabel & Indikator \\
\hline Tax Avoidance (Y) & Diproksikan dengan CETR, yaitu pembayaran kas untuk beban pajak dibagi \\
\hline Ref: Huseynov \& Klamm & laba sebelum pajak \\
\hline Damayanti \& Susanto (2015); & CFTR $=$ kas yang dibayarkan untuk beban pajah \\
\hline Dewinta \& Setiawan (2016) & laba sebelumpajak \\
\hline $\begin{array}{l}\text { Kualitas Audit (X1) } \\
\text { Ref: Beisland et al. (2012); Damayanti \& } \\
\text { Susanto (2015); } \\
\text { Kanagaretnam } \text { et al. (2016) }\end{array}$ & $\begin{array}{l}\text { Menggunakan variabel dummy yang mana bernilai } 1 \text { jika menggunakan jasa } \\
\text { auditor KAP the Big Four dan bernilai } 0 \text { jika tidak menggunakan jasa auditor } \\
\text { KAP non the Big Four. }\end{array}$ \\
\hline Komite Audit (X2) & Diproksikan dengan jumlah personil komite audit yang terdapat di perusahaan. \\
\hline $\begin{array}{l}\text { Ref: Annisa \& Kurniasih (2012); } \\
\text { Wibawa et al. (2016) }\end{array}$ & Komite Audit = Jumlah personil komite audit \\
\hline $\begin{array}{l}\text { Capital Intensity (X3) } \\
\text { Ref: Kraft (2014); Richardson et al. (2016) }\end{array}$ & $\begin{array}{l}\text { Diproksikan dengan rasio intensitas aset tetap, yaitu aset tetap dibagi total aset } \\
\text { yang dimiliki perusahaan. } \\
\mathbf{C I}=\frac{\text { aset tetap }}{\text { TotalAset }}\end{array}$ \\
\hline $\begin{array}{l}\text { Profitabilitas (X4) } \\
\text { Ref: Kabajeh et al. (2012); } \\
\text { Zarai (2013); } \\
\text { Damayanti \& Susanto (2015); Rizal (2016) }\end{array}$ & $\begin{array}{l}\text { Diproksikan dengan ROA, yaitu laba bersih dibagi dengan total aset yang } \\
\text { dimiliki perusahaan. } \\
\text { ROA }=\frac{\text { LabaBersih }}{\text { TotalAset }}\end{array}$ \\
\hline
\end{tabular}

Sumber: Data diolah, 2020

\section{HASIL DAN PEMBAHASAN}

Uji asumsi klasik dilakukan untuk memastikan bahwa model terbebas dari masalah multikolinearitas, heteroskedastisitas maupun autokorelasi. Uji Normalitas dengan uji statistik non-parametik Kolmogorov Smirnov Test (K-S) pada data dan diperoleh Asymp.Sig. (2-tailed) sebelum outlier sebesar 0.000, namun setelah dilakukan uji outlier dan dikeluarkan 8 data outlier, hasil keempat model regresi menjadi normal. Uji Heteroskedastisitas dilakukan dengan uji glejser yaitu dengan cara meregresikan variabel independen terhadap nilai absolute residual. Dari hasil uji glesjer, didapatkan semua variabel bernilai sig $>0,05$ yang berarti tidak terdapat gejala heterokedastisitas. Pada penelitian ini metode pengujian multikolinearitas yang digunakan yaitu dengan melihat nilai inflation factor (VIF) setiap variabel pada model regresi. Nilai VIF semua variabel adalah kurang dari 10, sehingga dapat disimpulkan bahwa tidak terjadi multikolinearitas antar variabel dalam penelitian. Uji Autokorelasi dalam penelitian ini menggunakan Run Test dan tidak terdapat gejala autokorelasi. Hasil uji regresi dapat dilihat pada tabel berikut: 
Jumriaty Jusman dan Firda Nosita, Pengaruh Corporate Governance, Capital Intensity dan Profitabilitas Terhadap Tax Avoidance pada Sektor Pertambangan

Tabel 2. Hasil regresi linear

\begin{tabular}{lccc}
\hline & Koefisien & Sig & Kesimpulan \\
\hline Constant & .418 & .000 & \\
Kualitas Audit & -.023 & .548 & Tidak Berpengaruh \\
Komite Audit & -.012 & .654 & Tidak Berpengaruh \\
CI & -.029 & .839 & Tidak Berpengaruh \\
ROA & -.429 & .005 & Berpengaruh \\
\hline
\end{tabular}

Sumber: Data diolah, 2020

Dari hasil uji regresi pada tabel 2 menunjukkan bahwa tata kelola perusahaan atau corporate governance yaitu kualitas audit dan komite audit tidak berpengaruh terhadap penghindaran pajak perusahaan-perusahaan sektor pertambangan yang terdaftar di Bursa Efek Indonesia. Capital Intensity juga terbukti tidak berpengaruh terhadap penghindaran pajak. Sedangkan profitabilitas yang diwakili oleh Return On Assets berpengaruh negatif signifikan terhadap penghindaran pajak.

Koefisien determinasi (R2) mengukur kemampuan variabel independen dalam mempengaruhi variabel dependennya. Besarnya pengaruh variabel independen terhadap variabel dependennya diperlihatkan dari nilai Adjusted $R$ Square. Berdasarkan Tabel 9 diperoleh angka Adjusted $R$ Square sebesar 0,127 atau $12,7 \%$. Hal ini menunjukkan bahwa persentase sumbangan pengaruh variabel bebas (kualitas audit, komite audit, capital intensity dan ROA) terhadap variabel terikat (tax avoidance) sebesar $12,7 \%$. Atau variabel bebas yang digunakan dalam model hanya mampu menjelaskan sebesar $12,7 \%$ variabel terikat, sedangkan sisanya sebesar $87,3 \%$ dipengaruhi atau dijelaskan oleh variabel lain yang tidak dimasukkan dalam model penelitian ini.

Tabel 3. Hasil Uji Determinasi

\begin{tabular}{ll|l|l|l}
\hline Model & $\mathrm{R}$ & $\mathrm{R}$ Square & $\begin{array}{l}\text { Adjusted R } \\
\text { Square }\end{array}$ & $\begin{array}{l}\text { Std. Error of the } \\
\text { Estimate }\end{array}$ \\
\hline 1 & $.438^{\mathrm{a}}$ & .192 & .127 & .111391 \\
\hline
\end{tabular}

Sumber: Data diolah, 2020

Berdasarakan hasil pengujian hipotesis dapat dilihat bahwa kualitas audit tidak berpengaruh signifikan terhadap tax avoidance. Penelitian ini sejalan penelitian yang dilakukan oleh Fadhilah (2014) serta Damayanti dan Susanto (2015) bahwa kualitas audit tidak berpengaruh signifikan terhadap tax avoidance. Perusahaan yang diaudit oleh KAP The big four memang lebih cenderung dipercayai oleh fiskus sebagai KAP yang mempunyai integritas kerja yang tinggi dengan selalu menerapkan peraturan-peraturan yang ada serta berkualitas, akan tetapi ada faktor-faktor yang mendorong auditor pada KAP melakukan perilaku disfungsional ketika melaksanakan tugas pengauditan, baik itu tindakan yang tidak secara langsung mempengaruhi kualitas audit, maupun tindakan yang mengurangi kualitas audit (Dharmawan, 2015). Perusahaan yang memakai jasa KAP the big four ataupun yang tidak memakai jasa KAP the big four tidak ada kaitannya dengan perilaku penghindaran pajak.

Berdasarakan hasil pengujian hipotesis variabel komite audit dapat dilihat bahwa komite audit tidak berpengaruh signifikan terhadap tax avoidance dengan nilai signifikansi $0,654>0,05$ Hasil penelitian ini mendukung penelitian yang dilakukan oleh Damayanti dan Susanto (2015), serta Zahra (2017). Menurut BEI dan Otoritas Jasa Keuangan, setiap perusahaan yang terdaftar di BEI wajib memiliki komite audit, yang anggotanya terdiri dari satu orang komisaris independen sebagai ketua dan minimal 2 orang pihak eksternal perusahaan yang independen sebagai anggota. Dewan komisaris wajib membentuk komite audit sekurangkurangnya tiga orang yang di angkat dan diberhentikan serta bertanggng jawab terhadap dewan komisaris. Jumlah komite audit terbukti tidak berperan dalam perilaku penghindaran pajak perusahaan. Berapapun jumlah anggota komite audit, tidak mempengaruhi perilaku perusahaan dalam menyikapi pajak yang harus dibayarkan. Komite audit bertugas untuk memastikan perusahaan dikelola sesuai dengan prinsip-prinsip Good Corporate Governance (GCG) dilaksanakan oleh perusahaan secara konsisten dan patuh terhadap perundang-undangan. Komite audit bertanggungjawab dalam memberikan pendapat professional dan independen kepada Dewan Komisaris perusahaan seperti penelaahan informasi keuangan, kepatuhan terhadap peraturan perundangan dan lainnya. Anggota komite audit biasanya diseleksi ketat dan dianggap memiliki integritas tinggi serta pengalaman dan kompetensi tertentu.

Berdasarakan hasil pengujian hipotesis variabel capital intensity dapat dilihat bahwa capital intensity tidak berpengaruh signifikan terhadap tax avoidance. Hasil penelitian ini mendukung penelitian yang dilakukan oleh Zahra (2017) serta Chiou et al. (2012). Hasil penelitian ini menunjukkan bahwa perusahaan menggunakan aset tetapnya untuk operasional perusahaan, bukan dipriotitaskan untuk memanfaatkan beban penyusutan aset tetap, yang mana beban penyusutan aset tetap secara fiskal merupakan beban yang dapat menjadi pengurang penghasilan kena pajak, sehingga dapat mengurangi pembayaran pajak penghasilan perusahaan. Perusahaan pertambangan biasanya memiliki aset tetap yang tinggi yang digunakan dalam operasionalnya. Pembelian aset tetap mungkin tidak bertujuan untuk mengambil manfaat pajak atas depresiasi aset, namun lebih kepada alasan operasional. Penggunaan metode penyusutan juga seringkali mempengaruhi laba yang didapatkan oleh perusahaan. Tujuan utama perusahaan selain memaksimalkan nilai, mereka turut memaksimalkan laba sebagai salah satu ukuran kinerja manajemen. Semakin besar laba, maka pajak yang dibayarkan juga akan semakin besar. 
Berdasarkan hasil pengujian hipotesis variabel ROA dapat dilihat bahwa ROA berpengaruh negatif signifikan terhadap tax avoidance. ROA merupakan indikator kemampuan perusahaan dalam menghasilkan laba sehingga ROA merupakan faktor penting dalam pengenaan pajak penghasilan bagi perusahaan. Perusahaan biasanya memiliki perencanaan pajak yang matang, sehingga pajak yang dibayarkan dapat optimal. Laba yang tinggi dapat berhubungan dengan berbagai kondisi, misal adanya efisiensi biaya, efisiensi operasi, maksimasi pemasaran dan sebagainya. Laba juga dapat dihubungkan dengan siklus bisnis perusahaan. Perusahaan yang sudah memasuki tahap growth biasanya memiliki laba yang tinggi dan fluktuatif sedangkan perusahaan yang berada pada siklus mature cenderung memiliki laba yang stabil. Dengan tingkat laba yang tinggi, perusahaan memiliki kemampuan untuk mentaati peraturan perpajakan dan bersedia membayar pajak tanpa mencari celah untuk menghindari pajak meskipun dengan cara-cara etis. Sebaliknya, perusahaan yang memiliki laba rendah mungkin akan "keberatan" membayar pajak karena laba yang rendah jika harus dikurangkan dengan pembayaran pajak, maka akan mempengaruhi persepsi kinerja manajemen dan mempengaruhi bonus yang didapatkan oleh Agent. Dengan kondisi tersebut, maka manajemen mungkin akan mencari celah perundang-undangan agar dapat meminimalkan pajak yang harus dibayarkan.

\section{SIMPULAN}

Hasil penelitian menunjukkan bahwa tata kelola perusahaan (Corporate Governance) yang diwakili oleh kualitas audit serta jumlah komite audit tidak berpengaruh signifikan terhadap penghindaran pajak. Hal ini membuktikan bahwa status KAP big four tidak berperan dalam perilaku penghindaran pajak perusahaan. Selain itu, jumlah anggota komite audit juga tidak berperan dalam penghindaran pajak. Anggota komite audit diseleksi ketat dan dituntut untuk memiliki integritas tinggi serta profesional, sehingga berapapun jumlah anggota komite audit tidak berpengaruh terhadap perilaku perusahaan dalam menghadapi kondisi perpajakannya. Hasil penelitian ini juga membuktikan bahwa intensitas modal (Capital Intensity) tidak berpengaruh signifikan terhadap penghindaran pajak. Perusahaan pertambangan cenderung memiliki aset tetap yang tinggi yang penting dalam operasional bisnisnya. Pemilikan aset tetap ini cenderung tidak berkaitan dengan usaha untuk menghindari pajak dengan memanfaatkan pengurangan pajak atas depresiasi aset tetap. Return On Assets (ROA) terbukti berpengaruh terhadap perilaku penghindaran pajak. Perusahaan yang memiliki profitabilitas tinggi cenderung taat pajak dan tidak mencari celah untuk mengurangi pajak yang dibayarkan. Sedangkan perusahaan dengan tingkat laba yang rendah cenderung berusaha menghindari pajak dengan mencari celah perundang-undangan yang ada.

Penelitian ini masih memiliki keterbatasan yaitu pengukuran tax avoidance masih bersifat taksiran dan pendekatan, bukan angka yang sebenarnya karena alasan untuk mendapatkan data pajak yang dibayar sebenarnya adalah sulit dan pengukuran tersebut dikalangan ahli masih diperdebatkan serta oleh para peneliti masih dicari kemungkinan alternatif proksi untuk ukuran tax avoidance. Serta Tingkat Adjusted $R 2$ yang rendah dari modal yang diuji $0,127(12,7 \%)$ dalam penelitian ini menunjukkan bahwa variabel lain yang tidak digunakan dalam penelitian ini mempunyai pengaruh yang lebih besar terhadap tax avoidance yang diproksikan dengan Cash Effective Tax Rate.

Peneliti selanjutnya sebaiknya mempertimbangkan menggunakan variabel lain yang mempengaruhi tax avoidance di luar variabel yang digunakan dalam penelitian ini dan apabila data pajak penghasilan perusahaan memungkinkan untuk diperoleh, maka data tersebut dapat digunakan sebagai proksi tax avoidance yang lebih akurat. Bagi Pemerintah hendaknya memberikan aturan yang jelas dan tegas antara penghindaran pajak yang diperbolehkan dengan penghindaran pajak yang tidak diperbolehkan sehingga perusahaan-perusahaan tidak berani untuk seenaknya melakukan penghindaran pajak yang menurut mereka suatu hal yang legal meskipun mereka mengetahui hal tersebut tidak diperbolehkan.

\section{DAFTAR PUSTAKA}

Annisa, N. A. dan Kurniasih, L. (2012). Pengaruh Corporate Governance terhadap Tax Avoidance. Jurnal Akuntansi \& Auditing, Vol.8, No.2. 123136. Doi:https://doi.org/10.14710/jaa.8.2.123-136.

Santosa, B. P dan Ashari. (2005) .Analisis Statistik dengan Microsoft Axcel\& SPSS.Yogyakarta. : ANDI.

Beisland, Leif A., Roy Mersland, dan R. Øystein Strøm. (2012). Audit Quality and Corporate Governance: Evidence from the Microfinance Industry. CEB Working Paper, 13/035.218-

Doi:https://doi.org/10.1111/ijau.12041.

Cahyono, Deddy D., R. Andini, dan K. Raharjo. (2016). Pengaruh Komite Audit, Kepemilikan

Institusional, Dewan Komisaris, Ukuran Perusahaan (Size), Leverage (DER) dan Profitabilitas (ROA) terhadap Tindakan Penghindaran Pajak (Tax Avoidance) pada Perusahaan Perbankan yang Listing BEI Periode Tahun 2011 - 2013. Journal of Accounting, Vol.2, No.2.

Chiou, Yong-Ching, Yao-Chih Hsieh, dan Wenyi Lin. (2012). Determinants of Effect Tax Rates for Firm Listed on China's Stock Markets: Panel Models with Two-Sided Censors. International 
Jumriaty Jusman dan Firda Nosita, Pengaruh Corporate Governance, Capital Intensity dan Profitabilitas Terhadap Tax Avoidance pada Sektor Pertambangan

Trade \& Academic Research Conference (ITARC), 3(1).

Dalu, Tatenda, Vincent G. Maposa, Stanford Pabwaungana, dan Tapiwa Dalu. 2012. The Impact of Tax Evasion and Avoidance on the Economy: A Case 78 of Harare, Zimbabwe.

African J. of Economic and Sustainable Development, Vo.1, No.3.284-296.

Damayanti, Fitri dan Tridahus Susanto. (2015). Pengaruh Komite Audit, Kualitas Audit, Kepemilikan Institusional, Risiko Perusahaan dan Return on Assets terhadap Tax Avoidance.

ESENSI Jurnal Bisnis dan Manajemen, Vol 5(2). 187-206.

Darsono Muadz Rizki, M. (2015). Pengaruh Corporate Social Responsibility dan Capital Intensity

Terhadap Penghindaran Pajak. Diponegoro Journal Of Accounting, Vol.4, No.3. 1-8.

Desai, Mihir A. dan Dhammika Dharmapala. (2009). Earnings Management and Corporate Tax Shelters. National Tax Journal Vol. 62, No. 1. 169-186.

Dewinta, I.,dan Setiawan, P., E. (2016). Pengaruh ukuran perusahaan, umur perusahaan, profitabilitas, leverage, dan pertumbuhan penjualan terhadap tax avoidance. E-Jurnal Akuntansi Universitas Udayana, Vol.14,3. 15841613.

Dharma Nyoman, B, S. dan Noviari, N. (2017). Pengaruh Corporate Social Responsibility dan Capital Intensity Terhadap Tax Avoidance. EJurnal Akuntansi Universitas Udayana, Vol.18,1. 529-556.

Dharmawan, N. A. S (2015). Studi analisis faktor penyebab disfungsional auditor dan upaya penanggulangan disfunsional auditor terhadap kualitas audit pada kantor akuntan publik di provinsi bali (studi kasus pada kantor akuntan publik "x" di wilayah denpasar, bali). Jurnal Ilmu Sosial dan Humaniora, Vol.4, No.1. 545-556.

Dharma, I. M. S dan Putu A. A. (2016). Pengaruh Leverage, Intensitas Aset Tetap, Ukuran Perusahaan, dan Koneksi Politik terhadap Tax Avoidance. E-Jurnal Akuntansi Universitas Udayana, Vol.15, No.1.

Fadhilah, R. (2014). Pengaruh good corporate governance terhadap tax avoidance. (studi empiris pada perusahaan manufaktur yang terdaftar di bei 2009-2011). Jurnal Akuntansi, Vo.2, No.1.122.

Feranika, A., at all. (2017). Pengaruh kepemilikan institusional, dewan komisaris independen, kualitas audit, komite audit, karakter eksekutif, dan laverage terhadap tax avoidance (studi empiris pada perusahaan manufaktur di BEI tahun pengamatan 2010-2014). Jurnal Akuntansi\& Keuangan UNJA, Vol.2, No.2. 12-21.

Gusnita, C. (2013, Agustus 26). Penghindaran pajak perusahaan global di dunia. Merdeka online. Diakses dari https://www.merdeka.com/peristiwa/penghindaran -pajak- perusahaan-global-di-dunia.html.

Huseynov, Faris dan Bonnie K. Klamm. (2012). Tax Avoidance, Tax Management and Corporate Social Responsibility. Journal of Corporate Finance, 18(4).

Kabajeh, M. A., M. Said M.A. AL Nu'aimat, dan Firas N. Dahmash. (2012). The Relationship between the ROA, ROE and ROI Ratios with Jordanian Insurance Public Companies Market Share Prices. International Journal of Humanities and Social Science, 2(11).

Kanagaretnam, Kiridaran, Kiat B.J. Lee, Chee Y. Lim, dan Gerald J. Lobo. (2016). Relation between Auditor Quality and Tax Aggressiveness: Implications of Cross-Country Institutional Differences. Auditing: A Journal of Practice and Theory, 35(4).

Kraft, A. (2014). What Really Affects German Firms' Effective Tax Rate? International Journal of Financial Research, 5(3).

Laporan keuangan dan pergerakan harga saham [online]. Diakses 5 Januari 2020 dari http://www.idx.co.id.

Prakosa, K. B. (2014). Pengaruh Profitabilitas, Kepemilikan Keluarga, dan Corporate Governance terhadap Penghindaran Pajak di Indonesia. Simposium Nasional Akuntansi XVII.

Rizal, M. (2016). Why Company Does Tax Avoidance? Evidence from a Manufacturing Company in Indonesia Stock Exchange. International Journal of Business and Management Invention, $5(5)$.

Sugianto, D. (2019, Juli 08). Sri Mulyani cermati dugaan Adaro hindari pajak. Finance detik Online. Diakses dari https://finance.detik.com/beritaekonomi-bisnis/d-4615931/sri- mulyanicermati-dugaan-adaro-hindari-pajak.

Wibawa, A. W. dan Yusri A. (2016). Pengaruh Good Corporate Governance terhadap Penghindaran Pajak (Studi pada Perusahaan Terdaftar di Indeks Bursa SRI KEHATI Tahun 2010-2014). Jurnal Perpajakan (JEJAK), 11(1).

Zahra, F. (2017). pengaruh corporate governance, profitabilitas, dan capital intensity terhadap penghindaran pajak. Skripsi. Universitas islam negeri syarif hidayatullah. Diakses dari http://repository.uinjkt.ac.id/dspace/handle/12345 6789/41134. 
Jumriaty Jusman dan Firda Nosita, Pengaruh Corporate Governance, Capital Intensity dan Profitabilitas Terhadap Tax Avoidance pada Sektor Pertambangan

Zarai, M. A. (2013). Corporate Tax Planning and Debt

Endogeneity: Case of American Firms.

International Journal of Business and Commerce,

$3(3)$. 